\title{
Prediction of Tall Crop Reference Evapotranspiration (ETr) and Trend Analysis for Udaipur Station, India
}

\author{
B.R. Jalgaonkar*, H.K. Mittal, P.M. Ingle, Mahesh Kothari and H.K. Jain \\ Department of Soil and Water Engineering, CTAE (MPUAT), Udaipur, Rajasthan, India \\ *Corresponding author
}

\begin{abstract}
A B S T R A C T
For accurate computation of crop water requirement, precise and globally acceptable method of estimating tall crop reference evapotranspiration i.e. Penman-Monteith was recommended by many authors. The method predicts tall crop reference evapotranspiration based on different climatic parameters. In present study, Penman-Monteith reference evapotranspiration at Udaipur station for period of 1991-2010 was calculated for tall crop reference surface. The analysis showed that daily tall crop reference evapotranspiration was ranged from $5.28 \mathrm{~mm} /$ day to $5.96 \mathrm{~mm} /$ day with mean of $5.54 \mathrm{~mm} /$ day. The annual tall crop reference evapotranspiration was ranged from $1928.18 \mathrm{~mm}$ to $2174.19 \mathrm{~mm}$. The influence of climatic parameters found that tall crop reference evapotranspiration was decreased due to increase maximum relative humidity and decreased bright sunshine hours. The decrease in tall crop reference evapotranspiration due to increase in maximum relative humidity by $77.22 \%$. The linear regression analysis showed that tall crop reference evapotranspiration (ETr) was decreasing during pre monsoon $(\mathrm{m}=-0.0061)$, post monsoon $(\mathrm{m}=-0.0169)$, rabi $(\mathrm{m}=-0.0017)$ and zaid $(\mathrm{m}=-0.0003)$ seasons respectively. The conformity of trend was done by Mann-Kendall test and no trend was found significant at $95 \%$ level $(\mathrm{z}= \pm 1.96)$ for all seasons at Udaipur station.
\end{abstract}

\section{Introduction}

The state Rajasthan has typical subtropical climate and characterized as which very hot summer and cold winter. The maximum temperature reached to more than as $45^{\circ} \mathrm{C}$ during summer and minimum temperature goes below $0^{\circ} \mathrm{C}$ during winter. The annual rainfall of Rajasthan varied from $164 \mathrm{~mm}$ at Jaisalmer to $1000 \mathrm{~mm}$ at Jhalawar districts with mean annual rainfall of $573 \mathrm{~mm}$. The large variation in temperature and other climatic parameters along with rainfall had paramount influence on crop water requirement. The crop water requirement for Udaipur station was estimated using Penman-
Monteith model by considering tall crop reference surface. The FAO-56 PenmanMonteith model accepted as the sole method of computing tall crop reference evapotranspiration which is based on meteorological data. The researchers studied the reference evapotranspiration estimation. Jabloun and Sahil (2008) evaluated the FAO56 methodology for estimating reference evapotranspiration using limited climatic data application to Tunisia for eight locations. The result showed that, the FAO-56 PenmanMontheith method was most adequate for calculating average daily evapotranspiration. 
Mehendale and Kadam (2010) studied sensitivity of evapotranspiration to solar radiation and vapour pressure deficit and metrological parameters. The result showed that relative humidity found to be most sensitive followed by sunshine hours, vapour pressure deficit, net solar radiation and temperature. The wind speed found to be less sensitive to the reference evapotranspiration. Praveen et al., (2011) studied the estimation of evapotranspiration rate by different methods for paddy crop in South Kodagu. They concluded that Penman-Monteith method was suitable for more precision in estimating evapotranspiration. Fisher and Pringle (2013) evaluated alternative methods for estimating reference evapotranspiration. They concluded that FAO-56 was found best method for estimation of reference evapotranspiration. Jhajharia et al., (2012) studied the trends of the reference evapotranspiration estimated through the Penman-Monteith method in the humid region of northeast India using Mann-Kendall (MK) test. The study found that annual and seasonal ETo was decreasing. The decrease in ETo was mainly attributed to the net radiation and wind speed. Karaburun et al., (2012) analyzed temperature on the basis of annual, seasonal, and monthly basis for the period of 1975 to 2006. They revealed that there was significantly increasing trend in temperature during the spring, summer and autumn; positive trends in the annual mean and maximum temperature with $90 \%$ and $99 \%$ significance levels. Khushu et al., (2012) studied temperature trends across the different zones of Jammu region. The study concluded that the temperature of five selected locations across Jammu regions was found increasing clearly indicated warming trend in region. The increase in temperature at the rate had adversely affected almost all crops of the region in terms of productivity and ultimately the total production of the State. Shan et al., (2015) studied the spatiotemporal trends of reference evapotranspiration and its driving factors in the Beijing-Tianjin sand source control project region, China. The results indicated that annual $\mathrm{ET}_{\mathrm{O}}$ had an insignificant decreasing trend in the study area, in which 15 stations showed significant negative trends and only one station showed significant positive trend at the $95 \%$ confidence level.

\section{Materials and Methods}

The Udaipur station lies between $24^{\circ} 35^{\prime}$ North Latitude and $73^{\circ} 41^{\prime}$ East Longitude with 600 $\mathrm{m}$ altitude. The location of study area is shown in figure 1 . The climatic parameters such as air temperature (maximum and minimum), relative humidity (maximum and minimum), wind speed, sunshine hours were collected from Indian Meteorological Department (IMD), Pune and Meteorological Observatory of the College of Technology and Engineering, Udaipur for 20 years period (1991-2010).

\section{Tall crop reference evapotranspiration estimation}

The tall crop reference evapotranspiration computation of tall crop reference surface using meteorological parameters at Udaipur was done using FAO Penman-Monteith method (Allen et al., 2005, ASCE 2008). The tall crop reference evapotranspiration was computed by assuming a hypothetical reference crop (Alfa-Alfa) with an assumed crop height of $0.50 \mathrm{~m}$, a fixed surface resistance of $45 \mathrm{~s} \mathrm{~m}^{-1}$ and albedo of 0.3 using equation

$$
E T_{r}=\frac{0.408 \Delta\left(R_{n}-G\right)+\gamma \frac{1600}{T+273} u_{2}\left(e_{s}-e_{a}\right)}{\Delta+\gamma\left(1+0.38 u_{2}\right)}
$$

Where, $\quad \mathrm{ET}_{\mathrm{r}}=$ Tall crop Reference evapotranspiration $\left[\mathrm{mm}\right.$ day $\left.^{-1}\right], \quad R_{n}=$ Net radiation at the crop surface $\left[\mathrm{MJ} \mathrm{m}^{-2} \mathrm{day}^{-1}\right], \mathrm{G}$ $=$ Soil heat flux density $\left[\mathrm{MJ} \mathrm{m}^{-2}\right.$ day $\left.^{-1}\right], \mathrm{T}=$ 
Mean daily air temperature at $2 \mathrm{~m}$ height $\left[{ }^{\circ} \mathrm{C}\right]$, $\mathrm{u}_{2}=$ Wind speed at $2 \mathrm{~m}$ height $\left[\mathrm{m} \mathrm{s}^{-1}\right], \mathrm{e}_{\mathrm{s}}=$ Saturation vapour pressure $[\mathrm{kPa}], \mathrm{e}_{\mathrm{a}}=$ Actual vapour pressure $[\mathrm{kPa}], \mathrm{e}_{\mathrm{s}}-\mathrm{e}_{\mathrm{a}}=$ Saturation vapour pressure deficit $[\mathrm{kPa}], \Delta=$ Slope vapour pressure curve $\left[\mathrm{kPa}{ }^{\circ} \mathrm{C}^{-1}\right], \quad \gamma=$ Psychometric constant $\left[\mathrm{kPa}^{\circ} \mathrm{C}^{-1}\right]$.

\section{Trend analysis}

The trend analysis for different climatic parameters and tall crop reference evapotranspiration was studied using linear regression trend and Mann-Kendall test method and described as below.

\section{Linear regression}

Linear regression consists of finding the best fitting straight line through the points. The best fitting line is called a regression line. The formula for a regression line is

$\mathrm{y}=\mathrm{mx}+\mathrm{C}$

Where, $\mathrm{y}=$ Predicted score, $\mathrm{m}=$ Slope of the line, $\mathrm{x}=$ regression coefficient, $\mathrm{C}=$ Intercept.

\section{Mann-Kendall test}

The Mann-Kendall test is a nonparametric test used for identifying trends in time series data. The test compares the relative magnitudes of sample data rather than the data values themselves both Kendall tau coefficient $(\tau)$ and Mann-Kendall coefficient (s) are nonparametric statistics used to find rank correlation. The following formula is used for calculating Mann-Kendall test:

$$
\mathrm{s}=\sum_{\mathrm{j}=1}^{\mathrm{j}=\mathrm{n}-1} \sum_{\mathrm{i}=\mathrm{j}+1}^{\mathrm{i}=\mathrm{n}} \operatorname{Sign}(\mathrm{Xi}-\mathrm{Xj})
$$

Where, $\mathrm{s}=$ The rating score (also called the Mann-Kendall sum), $\mathrm{x}=$ The data value $\mathrm{i}$ and $j=$ Counters, $n=$ Number of data values in the series, Sign $=$ A function having values of +1 , $0,-1$ if $(\mathrm{Xi}-\mathrm{Xj})$ is positive, zero, or negative, respectively. The normal distribution parameter (called the Mann-Kendall statistic, $\mathrm{Z}$ ) is calculated as follows:

$Z=\left\{\begin{array}{l}\frac{1}{\sigma}(s-1) \ldots s>0 \\ \quad 0 \ldots s=0 \\ \frac{1}{\sigma}(s+1) \ldots s<0\end{array}\right.$

\section{Sen slope estimator}

Sen's statistic is the median slope of each point-pair slope in a dataset (Sen, 1968). To perform the complete Sen's test, several rules and conditions should be satisfied; the time series should be equally spaced, i.e. the interval between data points should be equal. However, Sen's method considers missing data. The data should be sorted ascending according to time, and then apply the following formula to calculate Sen's slope estimator (Q) as the median of Sen's matrix members:

$Q=\operatorname{Median}\left\{\left[\left[\frac{X i-X j}{i-j}\right]_{j=1}^{j=n-1}\right]_{i=j+1}^{i=n}\right\}$

Where, $\mathrm{Q}=$ Sen's slope estimator, $\mathrm{x}=$ The data value $i$ and $j=$ Counters, $n=$ Number of data values in the series

\section{Results and Discussion}

\section{Tall crop reference evapotranspiration}

The tall crop reference evapotranspiration for Udaipur station, analysis showed that the daily tall crop reference evapotranspiration was ranged from $5.28 \mathrm{~mm} /$ day to 5.96 $\mathrm{mm} /$ day with mean of $5.54 \mathrm{~mm} /$ day. The maximum and minimum annual tall crop reference evapotranspiration was also estimated and found that it was $2174.19 \mathrm{~mm}$ during year 2000 and $1928.18 \mathrm{~mm}$ during year 2007. 
Fig.1 Location map of study area

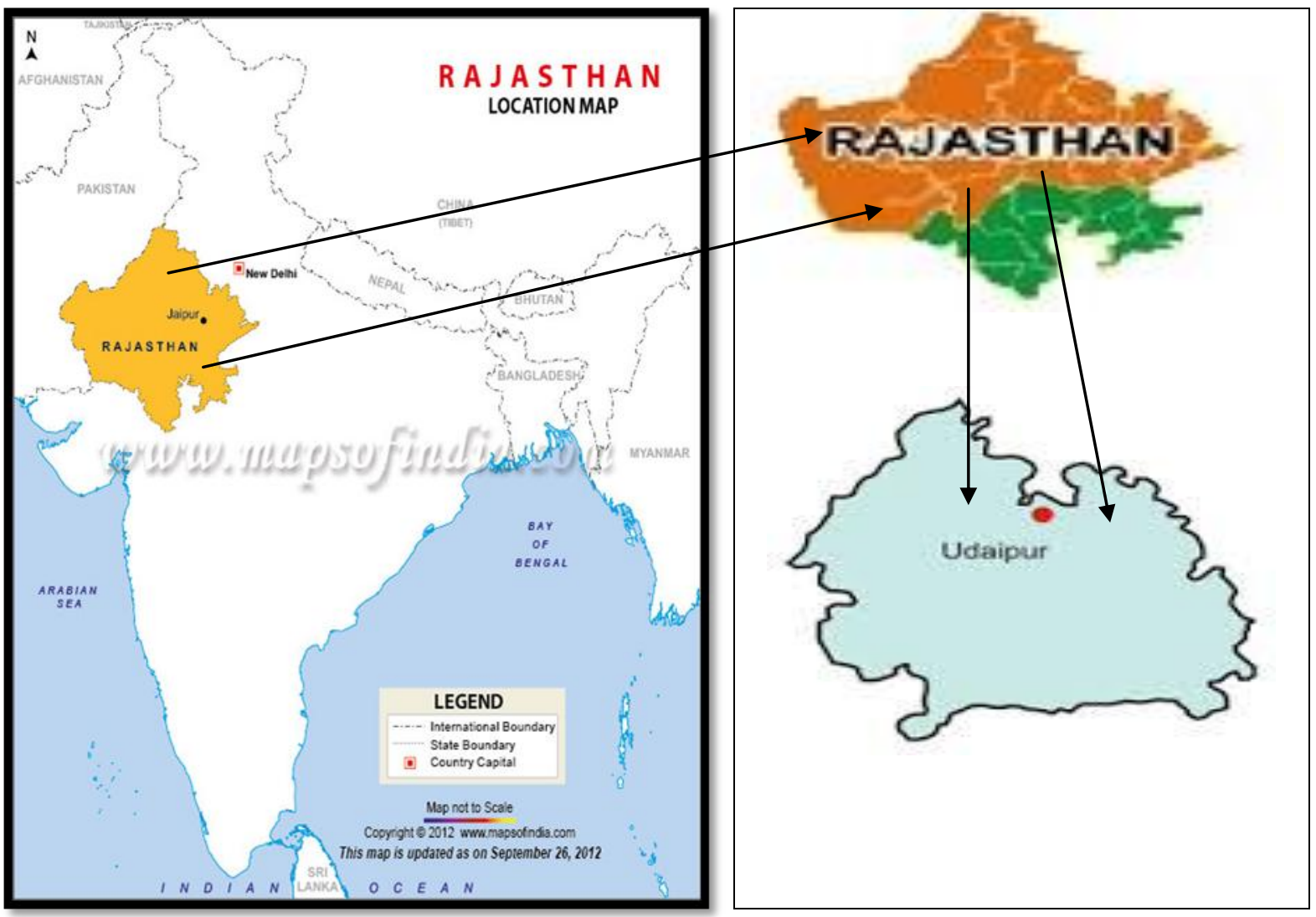

Fig.2 Daily tall crop reference evapotranspiration for Udaipur station

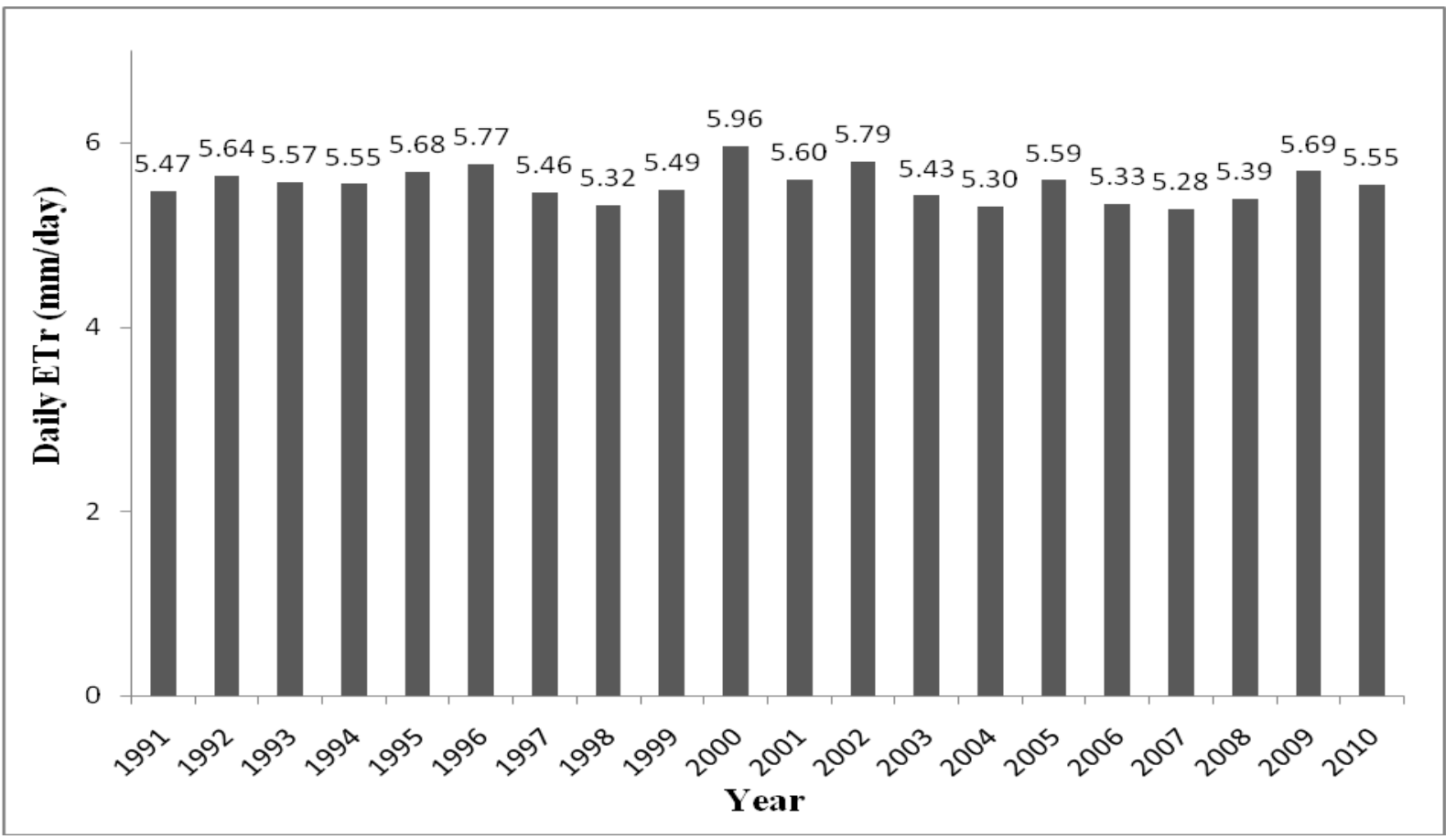


Fig.3 Annual tall crop reference evapotranspiration for Udaipur station

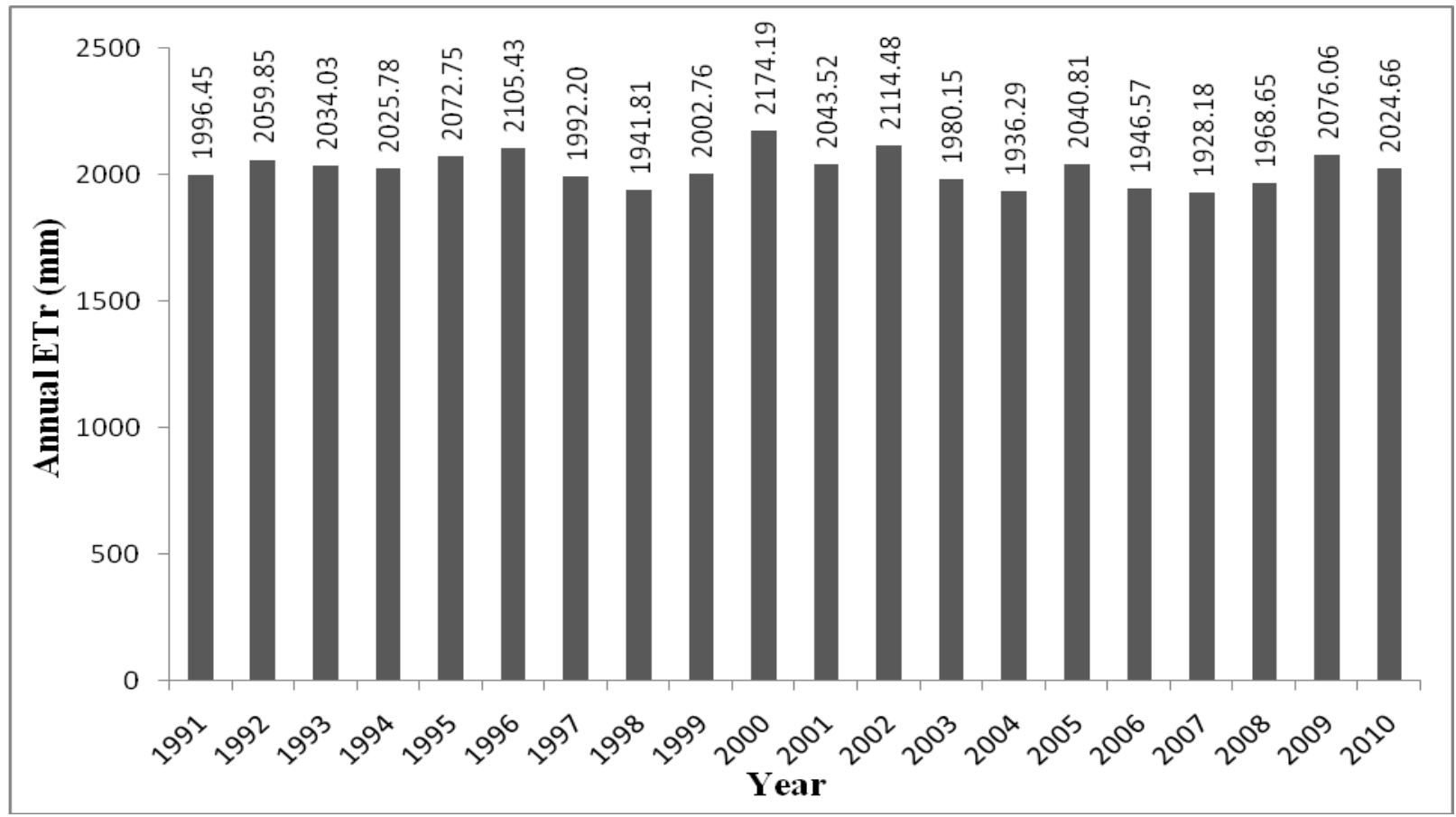

Fig.4 Linear trend analysis of tall crop reference evapotranspiration for Udaipur station

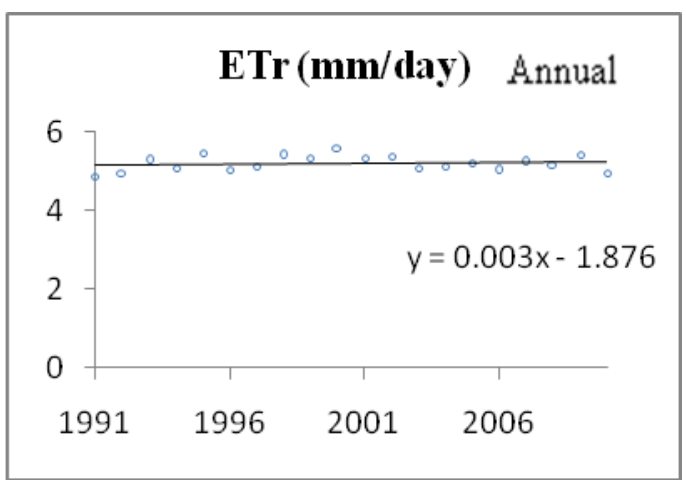

(a)

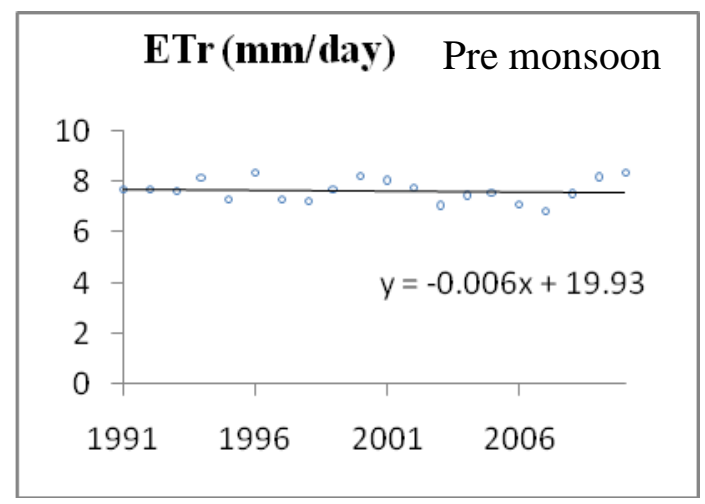

(c)

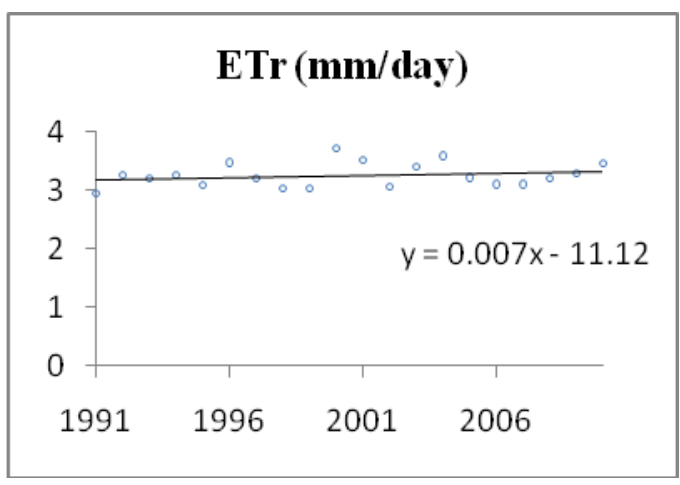

(b)

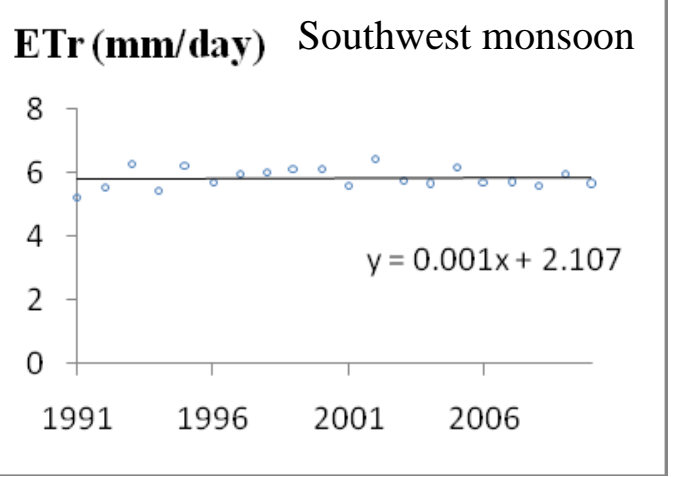

(d) 


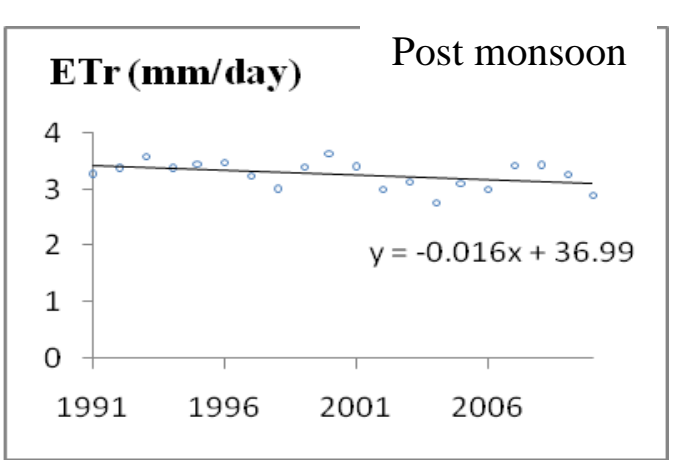

(e)

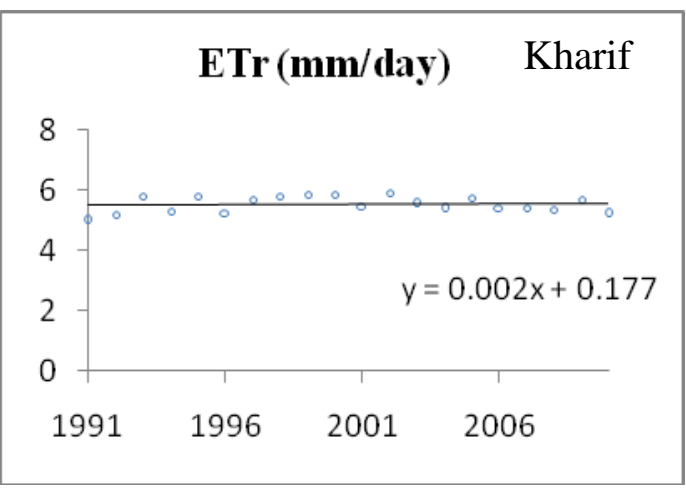

(g)

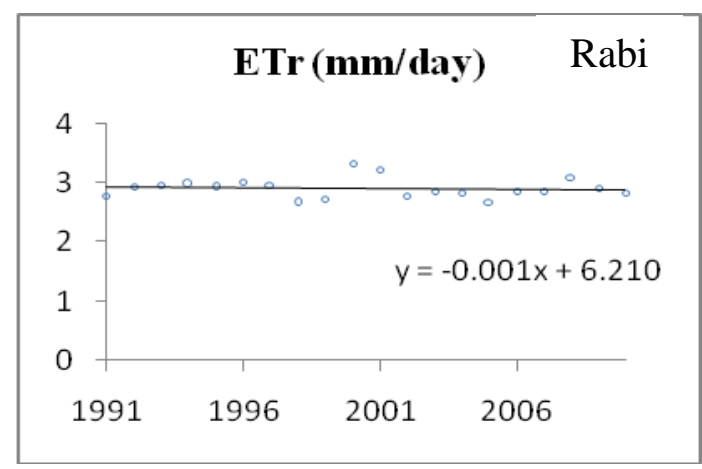

(f)

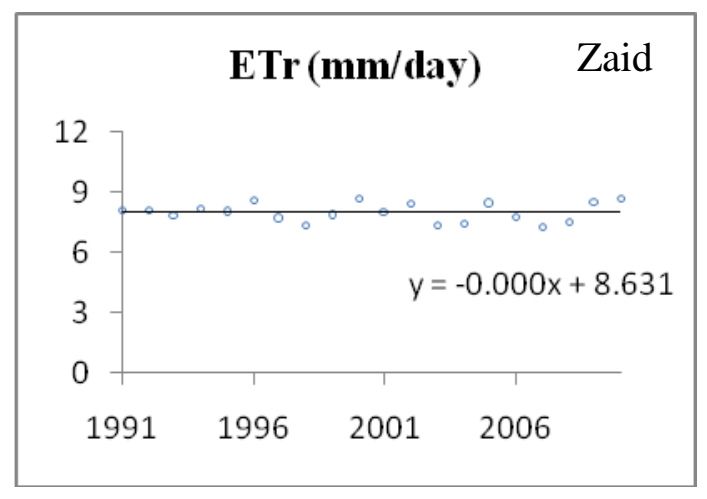

(h)

Fig.5 Trend analysis of tall crop reference evapotranspiration at different seasons for Udaipur station

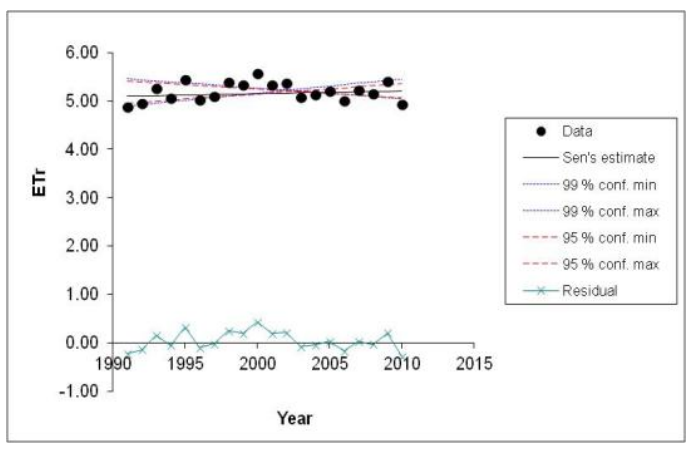

(a)

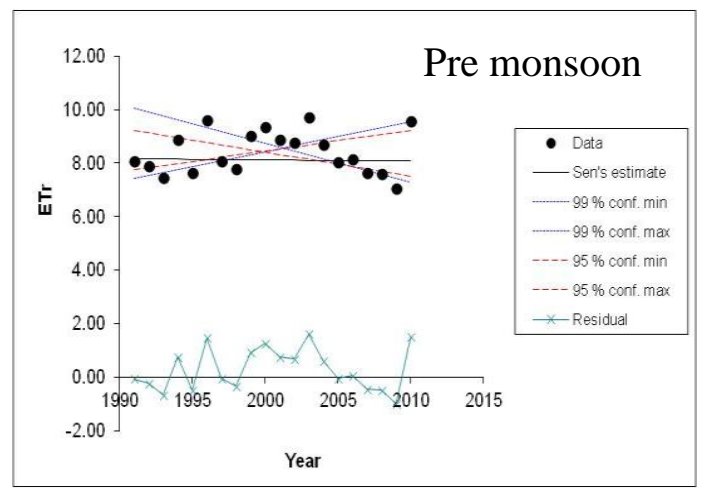

(c)

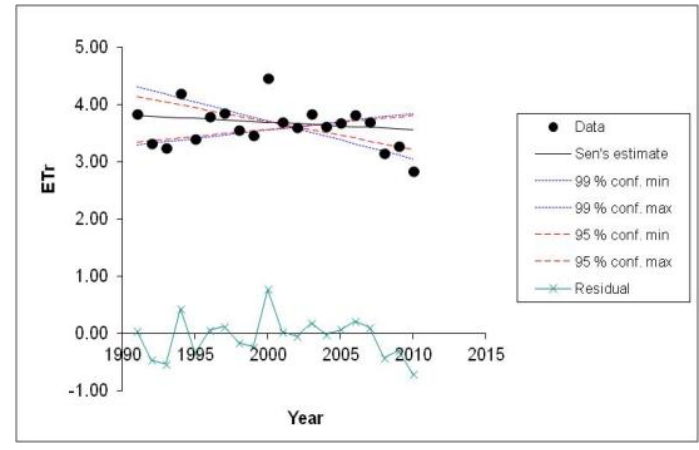

(b)

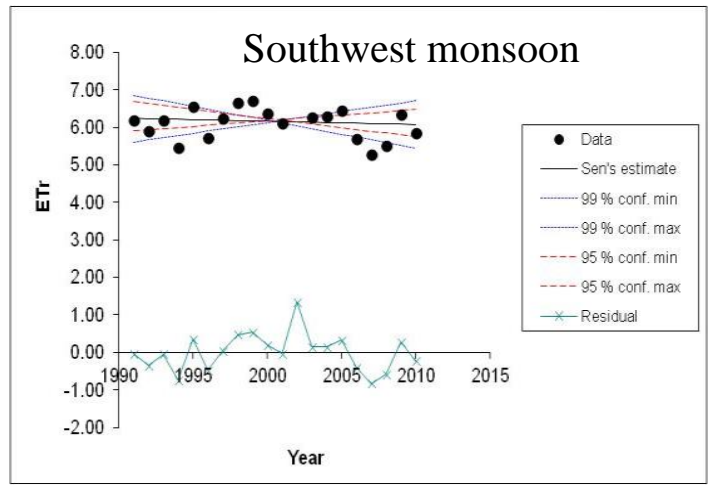

(d) 


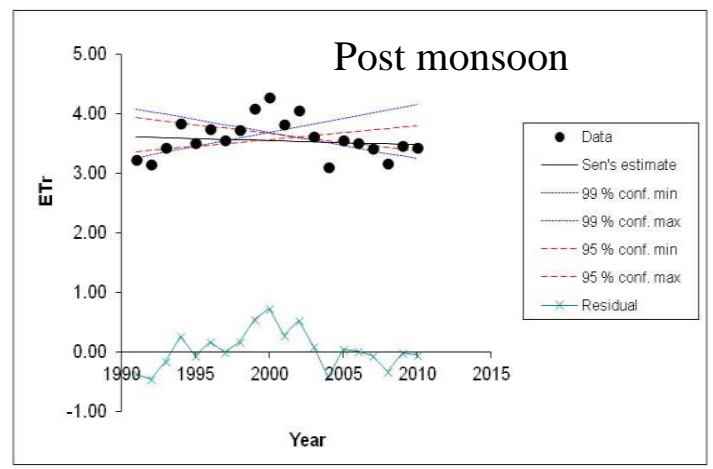

(e)

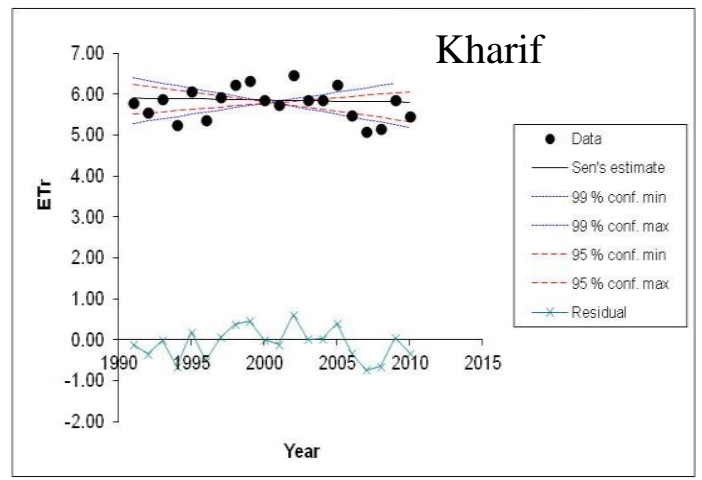

(g)

The mean annual tall crop reference evapotranspiration for Udaipur station was $2023.23 \mathrm{~mm}$. The maximum tall crop reference evapotranspiration was decrease due to increase maximum relative humidity and decreased due to bright sunshine hours. The lowest annual tall crop reference evapotranspiration observed during year 2007 due to increase in maximum relative humidity (77.22 \%). The daily and annual ETr for Udaipur station are shown in figures 2 and 3 respectively.

\section{Trend analysis}

The linear regression analysis was carried out for tall crop reference evapotranspiration (ETr) showed that the trend was decreasing during pre monsoon $(\mathrm{m}=-0.0061)$, post monsoon $(\mathrm{m}=-0.0169)$, rabi $(\mathrm{m}=-0.0017)$ and zaid $(\mathrm{m}=-0.0003)$ seasons respectively. The Mann-Kendall test was carried out and no trend was found at $95 \%$ level of significance $(\mathrm{z}= \pm 1.96)$ all seasons at Udaipur station.

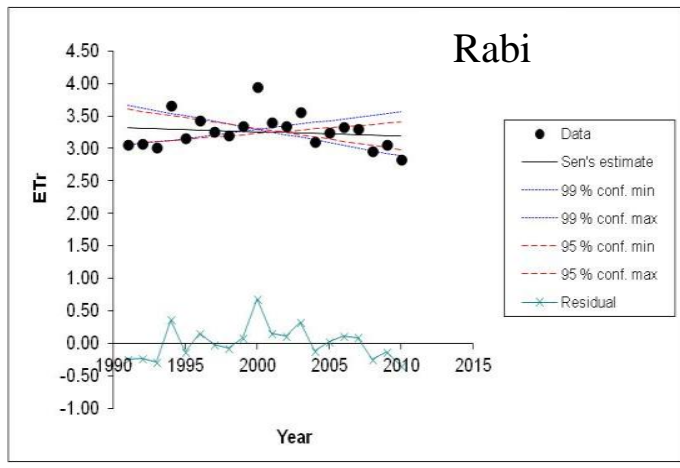

(f)

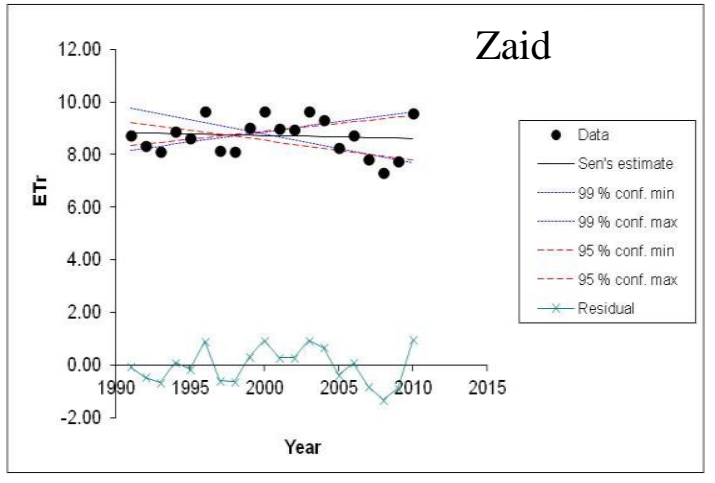

(h)

The detailed trend analysis using linear regression and MK test at Udaipur station is shown in figures 4 and 5 respectively.

The daily tall crop reference evapotranspiration ranged from $5.28 \mathrm{~mm} /$ day to $5.96 \mathrm{~mm} /$ day with mean of $5.54 \mathrm{~mm} /$ day. The annual tall crop reference evapotranspiration ranged from $1928.18 \mathrm{~mm}$ to $2174.19 \mathrm{~mm}$ at Udaipur stations. The trend analysis of tall crop reference evapotranspiration showed no trend for all season at Udaipur station. The estimation of tall crop reference evapotranspiration of Udaipur station found veryful for planning of water resources and prediction of crop water requirement. The trend analysis for different seasons showed the no trend in annual tall crop reference evapotranspiration. The seasonal trend analysis showed increase or decrease in tall crop reference evapotranspiration due to increment or disincrement of different climatic parameters of Udaipur station during different seasons. 


\section{References}

Allen, R.G., Pruitt, W.O., Wright, J.L., Howell, T.A., Ventura, F., Snyder, R., Itenfisu, D., Steduto, P., Berengena, J., Yrisarry, J.B. and Smith, M. 2006. A recommendation on standardized surface resistance for hourly calculation of reference ETo by the FAO56 Penman-Monteith method. Agri. Water Management, 81(1), pp.1-22.

Dinpashoh, Y., Jhajharia, D., Fakheri-Fard, A., Singh, V.P. and Kahya, E. 2011. Trends in reference crop evapotranspiration over Iran. J. Hydrol., 399(3), pp.422-433.

Fisher, D.K. and Pringle, H.C. 2013. Evaluation of alternative methods for estimating reference evapotranspiration. Agri. Sci.

Ingle, P.M., Nalawade, S.J., Aher R.P., Kadam U.S. and Manjarekar R.G. 2011. Computation of reference evapotranspiration for humid climate of Maharashtra State. J. Indian Sociol. Coastal Agri. Res., 29(1), pp.59-63.

Ingle, P.M., Kadam, U.S., Thokal, R.T. and Manjarekar, R.G. 2009. Prediction of reference evapotranspiration for konkan region of Maharashtra. J. Maharashtra Agri. Univ., 34(3), pp.314-318.

Jabloun, M.D. and Sahli, A. 2008. Evaluation of FAO-56 methodology for estimating reference evapotranspiration using limited climatic data: Application to Tunisia. Agri. Water Manage., 95(6), pp.707-715.

Jhajharia, D., Dinpashoh, Y., Kahya, E., Singh, V.P. and Fakheri-Fard, A. 2012. Trends in reference evapotranspiration in the humid region of northeast India. Hydrol. Processes, 26(3), pp.421-435.
Karaburun, A., Demirci, A. and Kara, F. 2012. Analysis of spatially distributed annual, seasonal and monthly temperatures in Marmara Region from 1975-2006. Ozean J. Appl. Sci., 5(2), pp.131-149.

Krishnakumar, K.N., Rao, G.P. and Gopakumar, C.S. 2009. Rainfall trends in twentieth century over Kerala, India. Atmospheric Environ., 43(11), pp.1940-1944.

Mehendale, G.M., and Kadam A.S. 2010. Sensitivity of evapotranspiration to solar radiation and vapour pressure deficit and other meteorological parameters. B. Tech. (Agril. Engg.) thesis submitted to College Of Agriculture And Engineering Technology, Dr. B.S.K.K.V. Dapoli, India.

Praveen, P., Devaranavadgi, V.S., Desai, G.A., Praveen, G.S. and Bai, K.R.M., 2011. Estimation of evapotranspiration rate by different methods for paddy crop in South Kodagu, Central Western Ghats. Int. J. Agri. Engi., 5(1), pp.69-72.

Singh, R.K. and Pawar, P.S. 2011. Comparative study of reference crop evapotranspiration (ETo) by different energy based method with FAO 56 Penman-Monteith method at New Delhi, India. Int. J. Engi. Sci. Technol., pp.7861-7868.

Singh, R.K. and Pawar, P.S. 2012. Comparison of reference evapotranspiratuion estimations across five diverse locations in India. Int. J. Appl. Innovator Engi. Manage., 1(4), pp.18-27.

Wang, X.M., Liu, H.J., Zhang, L.W. and Zhang, R.H. 2014. Climate change trend and its effects on reference evapotranspiration at Linhe Station, Hetao Irrigation District. Water Sci. Engi., 7(3), pp.250-266.

\section{How to cite this article:}

B.R. Jalgaonkar, H.K. Mittal, P.M. Ingle, Mahesh Kothari and Jain, H.K. 2017. Prediction of Tall Crop Reference Evapotranspiration (ETr) and Trend Analysis for Udaipur Station. Int.J.Curr.Microbiol.App.Sci. 6(7): 3948-3955. doi: https://doi.org/10.20546/ijcmas.2017.607.407 